\title{
New Trade Policy of EU: Implications for LDCs
}

\author{
Mohammad Masudur Rahman* and Cheong Inkyo**
}

\begin{abstract}
The European Union (EU) has notified its revised Generalized System of Preference (GSP) on 31 October, 2012 which will come into effect from 1 January, 2014. The EU is also in the process of, or contemplating, to sign Free Trade Agreements (FTAs) with many developing countries. Recently, EU has officially announced initiation of FTA negotiations with USA. Such preferential tariff arrangements could lead to significant erosion of preferences enjoyed currently by the Least Developed Countries (LDCS). In this backdrop, the main objective of the present study is to investigate the economic impacts originating from preference erosion in the EU market which could potentially affect LDCs in general, Bangladesh in particular. In this context, a dynamic computable general equilibrium (CGE) analysis has been developed by using the Global Trade Analysis Project (GTAP) model and database to explore the aggregate impact of the preferential erosion as well as sectoral implications for which different partial equilibrium analyses were used. The analysis evince that if the EU eliminates all tariffs for Pakistan, India and Vietnam, Bangladesh's real GDP could decrease by 0.27 percent whilst welfare loss could be to the tune of US\$ 54 million. Total exports to the EU will be reduced by 0.18 percent; consequently, Bangladesh's terms of trade and exports of textiles and clothing could be fall by about 1 percent. The product level disaggregated analysis using RCA and unit price of major items also indicate that a number of products including textiles and clothing will be confronted with formidable market access difficulties in the EU.
\end{abstract}

Keywords: Revised GSP; EU; GTAP; LDCs; Bangladesh; Pakistan; India; ASEAN. JEL Classification: $F 15$ \& F17

\footnotetext{
* Professor, School of Economics and Management Zhejiang A \& F University Linan, Hangzhou, China Email:masudbfti@gmail.com

${ }^{* *}$ Professor, Department of Economics, Inha University, Korea Email:inkyoc@gmail.com
} 


\section{Introduction}

On 25 October, 2012 the European Union (EU) issued its revised preferential import scheme known as the Generalized Scheme of Preferences (GSP) by adopting regulation no. $978 / 2012$ which will be effective from $1^{\text {st }}$ January 2014 . The GSP is a specific instrument focusing on a single dimension - preference for trade in goods only. The GSP is subject to WTO law, in particular to the GATT and the so-called "Enabling Clause". This allows for an exception to the WTO's "most-favored nation" principle (which stipulates that all WTO members should be accorded equal treatment). The revised GSP scheme will give preference to those countries which are in need preference the most. The new scheme is expected to include 89 beneficiary countries instead of the present 176 to ensure that countries most in need are given more prominence.

Under the revised GSP scheme, the Standard GSP will available to only 40 countries. In general there are 9383 tariff lines; number of tariff duty lines are 9572 . For 3173 tariff lines where beneficiary countries need to pay tariff, they will enjoy duty reduction. Beneficiary countries need to pay MFN duty only for 1075 tariff line. Under the standard GSP scheme the product graduation is to be initiated if a particular country exports products above a threshold level

The GSP+1) is an incentive-based mechanism of EU tariff preference policy by which preference is granted to promote economic growth of developing countries which are constrained by lack of export diversification and weak integration within the international trading system. For the new GSP scheme there are 15 potential countries which have an appropriately to get the preference of GSP+. If the candidate countries fulfill few conditions, they will enjoy the GSP+ benefits. Recently Pakistan was granted GSP plus by the EU parliament. Hence, Pakistan will enjoy duty free exports to EU market from January 1, 2014. The main benefit of GSP+ beneficiary countries is that there will be no product graduation. The tariff line under GSP+ scheme is the same as in standard GSP that is 9383 tariff line. Ad valorem duties for all products listed in GSP+ product list will enjoy zero tariffs irrespective of sensitive and non-sensitive preference. The beneficiary countries under the GSP+ scheme will enjoy zero duties on 6064 products and will need to pay MFN duty only on 1184 tariff line.

Under the EBA scheme, all 49 LDCs countries get duty free access to the EU market. It is an open-ended scheme and will not be changed. Under EBA scheme a beneficiary country can export all chapters under 1-97 except chapter 93. In addition, barring, 18

1) The EU parliament has approved GSP plus for Pakistan on November 5, 2013 (The Express Tribune, Nov. 6, 2013 www.tribue.com.pk) 
products of chapter 93, all products are eligible to enter to EU market under the EBA scheme.

As the number of beneficiaries under the GSP scheme is reduced and the product graduation list is increased, the EBA beneficiary countries may face reduced competitive pressure. To what extent this potential market can be captured by Bangladesh will depend on the capacity of Bangladesh's export sector to respond and also this will depend on the actions of other beneficiary countries under the new GSP scheme.

It is to be noted that, trade under GSP was worth US\$ 112 billion which represents around 5 percent of total EU imports and 11 percent of total EU imports from developing countries in 2011. US\$ 94 billion (83 percent) was traded through the standard GSP, US\$5.2 billion ( 5 percent) through GSP Plus and US\$13.6 billion (12 percent) under the Everything But Arms (EBA) scheme (EU 2012).

\subsection{EU-India FTA Proposed}

In October 2006, the European Union-India High Level Trade Group agreed the parameters for an ambitious Free Trade Agreement (FTA) between the two countries. For Europe, this was part of its 'Global Europe' initiative which aimed at setting up trade agreements with large and rapidly growing markets around the world. For India, this provided the prospect of preferential access to one of her major markets which already accounted for 22 percent of her total exports. The negotiations for the FTA, formally called the EU-India Broad-based Trade and Investment Agreement (BTIA), started in 2005. Till now, 13 rounds of formal negotiations have been held. However, the long-negotiated ambitious FTA between India and its largest trading partner EU may remain in the doldrums till a new government takes over in New Delhi in the second half of 2014.

The EU is India's largest trading partner, accounting for approximately US\$ 112.78 billion in trade in goods in 2011. India and the European Union expect to reach a bilateral trade of US\$ 200 billion by 2015 which is one of the objectives that initiated this FTA (bilaterals.org). As India is the one of important competitors of Bangladesh in the EU market. The primary objective of this section is to investigate the potential economic impacts of the proposed EU-India Free Trade Agreement on LDCs in general, and on Bangladesh, in particular. 


\subsection{EU-ASEAN FTA Proposed}

The EU has been striving to strengthen its partnership with the ASEAN for many years. On 4 May 2007, the two sides agreed to start negotiations. The Bandar Seri Bagwan Plan of Action was signed in 2012 between the two partners to strengthen the EU-ASEAN enhanced partnership (2013-2017). ASEAN's Exports to EU was US\$134.06 billion which is 10 percent of their total exports in 2012 and their imports from EU was US\$117.1 billion which was around 9 percent of the total imports.

The EU-ASEAN FTA is supposed to be a comprehensive agreement. The talks have moved slowly and it's not clear if the final deal will take the form of separate agreements between the EU and individual ASEAN members, something the EU seems to prefer. While the EU and Singapore have just completed negotiation, Thailand has become the latest ASEAN member to launch FTA talks with the EU and in advanced stages in negotiations. Vietnam-EU FTA negotiation has also been launched. These countries are working hard to conclude negotiations by the end of 2014, which is expected to accelerate Vietnam-EU economic and trade ties. Recently, Myanmar has also been received EBA from the EU.

In this backdrop, it seems these individual FTAs can eventually serve as building blocs on which the original region- to region FTA plan which was dropped in 2009. As most of the ASEAN countries are main competitors of Bangladesh vis-à-vis the EU market, it is necessary to analyze how far the EU's conclusion of FTA with these countries will impact Bangladesh's exports to the EU.

\subsection{The Transatlantic Trade and Investment Partnership: EU-USA FTA Proposed}

On 13 February 2013, the President of the United States, the President of the European Commission and the President of the European Council made a joint announcement to be effect that the EU and the USA have agreed to launch negotiations on a Transatlantic Trade and Investment Partnership (TTIP) with the aim of signing an agreement in 2015.2) The main objective of this section is to examine the potential impact of the proposed EU-USA FTA on the LDCs. The key issues that are considered here relate to identification of the most important products in US or EU imports from LDCs and how vulnerable the products are to trade diversion/preference erosion. As far as tariffs are concerned, the European Union and the USA currently apply most favored nation (MFN) tariffs in trading with one

2) European Commission (2013) (MEMO/13/95) "European Union and United States to Launch Negotiations for a Transatlantic Trade and Investment Partnership" 
another. These MFN tariffs will be abolished if this transatlantic trade deal is signed. The size of losses in terms of competitiveness of the excluded countries will depend on the degree to which such tariff elimination will impact on their relative competitive strength of these excluded countries.

\section{Trade and Tariff Structure Among Major Trading Countries}

Table 1 shows the trade share of Bangladesh, Pakistan, India and other ASEAN countries trade in the EU market. Bangladesh's total exports to EU were US\$13.77 billion, approximately 57 percent of its exports in 2011. At the same time Pakistan's total exports to the EU were US\$ 6.3 billion or about 28 percent of its total exports and India's total exports to the EU were US\$ 57 billion in 2011. In 2011, ASEAN was the EU's third largest trading partner outside Europe; while the EU was ASEAN's third largest trading partner globally (EU 2012). ASEAN's Exports to EU was US\$134.06 billion which is 10 percent of their total exports in 2011 and their imports from EU was US\$117.1 billion which was around 9 percent of the total imports. Vietnam's exports were US\$17.8 billion in 2011. Thailand exports US\$ 24.2 billion, Indonesia's export US\$20.5 billion, Singapore US\$ 39 billion and Cambodia's exports US\$ 1.52 billion respectively in 2011. This indicates that the EU is a very important trading partner for Bangladesh, India, Pakistan as well as ASEAN Countries. Moreover EU-USA is the biggest trading partner in the world. The total trade between USA-EU was US\$ 676 billion in 2012 where EU exported to USA around US\$ 400 billion.

\section{Table 1.}

Bangladesh, India, Pakistan and Vietnam's Trade with the EU and the Rest of the World in 2011

Value in US\$ Billion

\begin{tabular}{|c|c|c|c|c|c|c|}
\hline Countries & \multicolumn{2}{|c|}{ EU } & \multicolumn{2}{c|}{ USA } & \multicolumn{2}{c|}{ Rest of the World } \\
\hline & Value & Share & Value & Share & Value & Share \\
\hline Bangladesh's Exports & 13.77 & $57 \%$ & 5.08 & $19 \%$ & 7.76 & $24 \%$ \\
\hline Bangladesh's Imports & 2.3 & $8 \%$ & 0.8 & $3 \%$ & 27.07 & $89 \%$ \\
\hline Bangladesh's Total Trade & 16.07 & $28 \%$ & 5.88 & $10 \%$ & 34.88 & $62 \%$ \\
\hline Pakistan's Exports & 6.3 & $28 \%$ & 4 & $17 \%$ & 12.58 & $55 \%$ \\
\hline
\end{tabular}




\begin{tabular}{|c|c|c|c|c|c|c|}
\hline Countries & \multicolumn{2}{|c|}{$\mathbf{E U}$} & \multicolumn{2}{|c|}{ USA } & \multicolumn{2}{|c|}{ Rest of the World } \\
\hline Pakistan's Imports & 4.5 & $15 \%$ & 1.8 & $6 \%$ & 24.43 & $79 \%$ \\
\hline Pakistan's Total Trade & 10.8 & $20 \%$ & 5.8 & $11 \%$ & 36.80 & $69 \%$ \\
\hline India's Exports & 57.08 & $23 \%$ & 37.05 & $15 \%$ & 150.15 & $62 \%$ \\
\hline India's Imports & 55.7 & $20 \%$ & 16.67 & $6 \%$ & 207.10 & $74 \%$ \\
\hline India's Total Trade & 112.78 & $22 \%$ & 53.72 & $10 \%$ & 357.13 & $68 \%$ \\
\hline Vietnam's Exports & 17.83 & $18 \%$ & 18.38 & $19 \%$ & 61.63 & $63 \%$ \\
\hline Vietnam's Imports & 6.51 & $6 \%$ & 4.08 & $4 \%$ & 96.84 & $90 \%$ \\
\hline Vietnam's Total Trade & 24.34 & $12 \%$ & 22.46 & $11 \%$ & 158.12 & $77 \%$ \\
\hline Indonesia's Exports & 20.53 & $10 \%$ & 16.49 & $8 \%$ & 166.47 & $81 \%$ \\
\hline Indonesia's Imports & 12.50 & $7 \%$ & 10.83 & $6 \%$ & 154.10 & $86 \%$ \\
\hline Indonesia's Total Trade & 33.03 & $8 \%$ & 27.32 & $7 \%$ & 320.58 & $84 \%$ \\
\hline Myanmar's Exports (2010) & 0.09 & $1 \%$ & 0.001 & $0 \%$ & 7.53 & $98 \%$ \\
\hline Myanmar's Imports (2010) & 0.06 & $1 \%$ & 0.024 & $0 \%$ & 4.08 & $97 \%$ \\
\hline Myanmar's Total Trade (2010) & 0.15 & $1 \%$ & 0.025 & $0 \%$ & 11.61 & $98 \%$ \\
\hline Cambodia's Exports & 1.52 & $22 \%$ & 2.11 & $31 \%$ & 3.07 & $45 \%$ \\
\hline Cambodia's Imports & 0.19 & $3 \%$ & 0.14 & $2 \%$ & 5.81 & $94 \%$ \\
\hline Cambodia's Total Trade & 1.71 & $13 \%$ & 2.25 & $17 \%$ & 8.88 & $69 \%$ \\
\hline Thailand's Exports & 24.23 & $10 \%$ & 21.89 & $9 \%$ & 182.70 & $79 \%$ \\
\hline Thailand's Imports & 17.84 & $7 \%$ & 13.47 & $5 \%$ & 197.17 & $86 \%$ \\
\hline Thailand's Total Trade & 42.07 & $9 \%$ & 35.36 & $7 \%$ & 379.87 & $83 \%$ \\
\hline Singapore's Exports & 39.25 & $9 \%$ & 22.36 & $5 \%$ & 377.89 & $92 \%$ \\
\hline Singapore's Imports & 46.08 & $12 \%$ & 39.50 & $10 \%$ & 280.19 & $76 \%$ \\
\hline Singapore's Total Trade & 85.33 & $11 \%$ & 61.86 & $7 \%$ & 658.08 & $84 \%$ \\
\hline
\end{tabular}

Source: WITS 2013(Mirror \& Direct data) 


\section{Table 2.}

Tariff Imposed by the EU on Bangladesh, Pakistan, India, Vietnam and US

\begin{tabular}{|c|c|c|c|c|c|c|}
\hline \multirow{2}{*}{ Year } & \multirow{2}{*}{$\begin{array}{c}\text { Prod } \\
\text { uct }\end{array}$} & Bangladesh & Pakistan & India & Vietnam & US \\
\cline { 3 - 7 } & AHS & AHS & AHS & AHS & 4.25 \\
\hline 2007 & All & 0.00 & 2.87 & 4.04 & 4.28 & 4.23 \\
\hline 2008 & All & 0.00 & 2.82 & 4.02 & 4.21 & 4.23 \\
\hline 2009 & All & 0.00 & 2.82 & 4.02 & 4.21 & 4.1 \\
\hline 2010 & All & 0.00 & 2.78 & 4.23 & 4.27 & 4.1 \\
\hline
\end{tabular}

Source: WITS, Aggregated from 6-Digit data using TradeSift4) and Eurostat (http://epp.eurostat.ec.europa.eu)

Table 2 shows the import tariff structure imposed by the EU on Bangladesh and the other five countries. Bangladesh has had zero tariff duties to the EU under the EBA scheme but Pakistan, India, Vietnam and USA have to pay some duties to enter the EU market. If Pakistan or other competitor countries receive GSP+ preferences or signing a FTA, then Bangladesh will certainly lose its preference in the EU market.

Simple average tariff of the EU against the USA is 4.1 percent and the average US MFN tariff against the EU is 3.5 percent. These are not high average tariffs and as such do not suggest a Free Trade Agreement (FTA) would endow major competitive advantage to either the EU or the USA through transatlantic trade. While the average tariff between the USA and EU stands 3-4 percent, non-tariff barriers are extremely high, ranging from 25.5 73.3 percent.5) Therefore, elimination of non-tariff barriers may actually cause more damage to the LDCs than elimination of tariffs. Therefore it is necessary to identify the affected products as well as measure the intensity of erosion of preferences of these products.

\subsection{Export Similarity of Bangladesh, Pakistan, India and Vietnam in the EU Market:}

As it is known, a highly similar export basket will have greater impact if both countries' primary destination is the same. It is therefore very important to determine the similarity of Bangladesh's, Pakistan's, India's and Vietnam's exports to the EU. The widely

\footnotetext{
3) AHS means Effectively Applied Rate which is charged at the border.

4) TradeSift Software

5) ECORYS (2009), Non-Tariff Measures in EU-US Trade and Investment-An Economic Analysis. p .xix, xx
} 
known Finger Kreinin Index $\left.(\mathrm{FKI})^{6}\right)$ is used to find the similarity of Bangladesh and the other exporters to the EU as well as to the world market.

Table 3.

FKI $^{7}$ ) of Four Countries in the EU and the World

\begin{tabular}{|c|c|c|c|c|c|c|}
\hline Reporter 1 & Reporter 2 & Partner & 2008 & 2009 & 2010 & 2011 \\
\hline \multicolumn{7}{|c|}{ 6-Digit Leve } \\
\hline Bangladesh & Pakistan & EU-27 & 0.20 & 0.21 & 0.22 & 0.23 \\
\hline Bangladesh & Pakistan & World & 0.17 & 0.16 & 0.16 & 0.17 \\
\hline Bangladesh & India & EU-27 & 0.17 & 0.17 & 0.16 & 0.16 \\
\hline Bangladesh & India & World & 0.12 & 0.12 & 0.11 & 0.11 \\
\hline Bangladesh & Viet Nam & EU-27 & 0.15 & 0.15 & 0.14 & 0.14 \\
\hline Bangladesh & Viet Nam & World & 0.19 & 0.19 & 0.20 & 0.21 \\
\hline \multicolumn{7}{|c|}{ Top 100 Exports products } \\
\hline Bangladesh & Pakistan & EU-27 & 0.37 & 0.35 & 0.34 & 0.37 \\
\hline Bangladesh & India & EU-27 & 0.34 & 0.33 & 0.32 & 0.32 \\
\hline Bangladesh & Viet Nam & EU-27 & 0.20 & 0.21 & 0.20 & 0.21 \\
\hline
\end{tabular}

Source: Authors' calculation by using TradeSift (V2.0) taking data from WITS

6) It ranges between 0 and 1 . If 0 , then the two structures are completely different. The products that Bangladesh exports are not exported by India and vice versa. If 1 , then the two structures are identical. Both countries export the same products and with the same intensity.

7) The FKI index reveals the degree of similarity between either the structure of imports or exports or the structure of production between two countries.

$F K_{i j}^{k}=\sum_{i} \min \left[\left(\frac{x_{i 1 j}^{k}}{X_{i 1 j}}\right),\left(\frac{x_{i 2 j}^{k}}{X_{i 2 j}}\right)\right]$

Where

$x_{i 1 j}^{k}=$ Country $i 1$ export of $k$ product to country $j$

$X_{i 1 j}=$ Country $i 1$ export of total product to country $j$

$x_{i 2 j}^{k}=$ Country $i 2$ export of $k$ product to country $j$

$X_{i 2 j}=$ Country $i 2$ export of total product to country $j$ 
In table 3 the Finger Kreinin Index shows that similarities of Bangladesh and Pakistan's exports to the EU have been increasing over the years. Similarity was 20 percent in 2008 which rose to 23 percent in 2011. This rises similarity could lead to higher impact as both Bangladesh and Pakistan are competitive in the export of clothing items to the EU. Table 3 also indicates that 37 percent of Bangladesh's top 100 products can be categorized as similar exports to the EU market. This would, thus mean that Pakistan is a leading competitor of her in the EU market.

Table 3 also shows the degree of similarity between Bangladeshi and Indian exports to the EU and the world in all products as well as in the top 100 product category. The table shows falling similarities in time yet the overlap in exporting structures nears 16 percent in 2011 in the EU market. This implies that India has the potential of displacing Bangladeshi exports.

The degree of overlap between the exporting structures of Bangladesh and Vietnam in all products and in the top 100 product category is shown in Table 3. The table shows a decreasing overlap over time with respect to the EU implying that Vietnam is becoming less of a competitor in the EU market. However, when we look at the figures for the world, we see that the similarity between Vietnamese and Bangladeshi exports to the world is stable and is higher than that in the EU. It is possible that the divergence in the EU is because of the EBA preferences awarded to Bangladesh. These figures suggest that Vietnam could be a strong competitor in the EU market and hence has the potential to displace Bangladeshi exports.

\section{Table 4.}

Utilization Rate of GSP of Bangladesh's main Competitors (\%)

\begin{tabular}{|c|c|c|c|c|c|c|c|c|c|}
\hline \multirow{2}{*}{ Countries } & \multicolumn{3}{|c|}{2010} & \multicolumn{3}{c|}{2011} & \multicolumn{3}{c|}{2012} \\
\cline { 2 - 10 } & Zero & $\begin{array}{c}\text { Non } \\
\text { Zero }\end{array}$ & Utilization & Zero & $\begin{array}{c}\text { Non } \\
\text { Zero }\end{array}$ & Utilization & Zero & $\begin{array}{c}\text { Non } \\
\text { Zero }\end{array}$ & Utilization \\
\hline Bangladesh & 83.1 & - & 83.1 & 92.75 & & 92.75 & 94.35 & & 94.3 \\
\hline India & 21.1 & 25.4 & 46.6 & 22.23 & 23.9 & 46.16 & 22.51 & 21.4 & 43.9 \\
\hline Pakistan & 11.2 & 68.9 & 80.2 & 9.72 & 69.1 & 78.81 & 10.81 & 68.1 & 78.9 \\
\hline Viet Nam & 9.0 & 14.2 & 23.2 & 8.06 & 12.3 & 20.38 & 5.92 & 8.7 & 14.6 \\
\hline
\end{tabular}

Source: Author's Calculation based on Data from Euro Stat

The table 4 shows the GSP utilization rate by Bangladesh, India, Pakistan and Vietnam in the EU market over last three years. This indicates that under GSP preference 
(non-zero) Pakistan's utilization rate is very high compared to India and Vietnam. This indicates that Pakistan has huge export potential to in the EU market if they get zero duty. The Indian GSP utilization rate under non-zero tariff is also significantly high but lower than Pakistan. This implies that Pakistan and India have huge export potential in the EU market and strong competitors of Bangladesh. The GSP preference utilization rate of Vietnam is lower compared to Pakistan and India which indicates that Vietnam is less competitors in the EU market.

\section{The GTAP Model for Macroeconomic Analysis8)}

The most common modeling technique for estimating economic impacts of a trade agreement with economy-wide effects involves the computable general equilibrium (CGE) modeling framework of the Global Trade Analysis Project (GTAP). The general equilibrium model is thoroughly documented in Hertel (1997) and in the GTAP database documentation (Dimaranan, 2006). It is a comparative static multi-regional CGE model.

The basic structure of the GTAP database includes: industrial sectors, households, governments, and global sectors across countries. Countries and regions in the world economy are linked together through trade. Prices and quantities are simultaneously determined in both factor markets and commodity markets. The main factors of production are skilled and unskilled labor, capital, natural resources and land.

Producers operate under constant returns to scale, where the technology is described by the Leontief and CES functions. Two broad categories of inputs are identified: intermediate inputs and primary factors of productions. In the model, firms minimize costs of inputs given their level of output and fixed technology. First, producers use composite units of intermediate inputs and primary factors in fixed proportions following a Leontief production function. At the second level of the production nest, intermediate input composites are obtained combining imported bundles and domestic goods of the same input-output group. Trade policy can affect the price of traded goods relative to domestically produced goods. As a result, a key relationship for model analysis is the degree of substitution between imported and domestic goods. This key relationship is commonly identified as the Armington elasticity.9) It is assumed that domestically produced goods and imports are imperfectly substituted. This is modeled using the

8) Hertel, T.W. (1997), Global Trade Analysis: Modeling and Applications and the GTAP website at https://www.gtap.agecon.purdue.edu for a full introduction to the database.

9) The constant elasticity of substitution (CES) specification for the trade substitution elasticity is derived from Armington (1969). 
Armington structure.

Households' behavior in the model is determined from an aggregate utility function. The aggregate utility is modeled using a Cobb-Douglas production function with constant expenditure shares. This utility function includes private consumption, government consumption and savings. Current government expenditure goes into the regional household utility function as a proxy for government provision of public goods and services. Private households' consumption is explained by a constant difference elasticity expenditure function.

Domestic support and trade policy (tariff barriers) are modeled as ad valorem equivalents. These policies have a direct impact on the production and consumption sectors in the model. In equilibrium, all firms have zero real profit, all households are on their budget constraint, and global investment is equal to global savings. Changing the model's parameters allows one to estimate the impact from a country's/region's original equilibrium position to a new equilibrium position.

The GTAP framework has strength because of theoretical rigor, its ability to represent direct and indirect interactions among all sectors of an economy and precise detailed quantitative results. The strength of the multi-country CGE model is that incorporates in an elegant manner, the features of neo-classical general equilibrium and real international trade models in an empirical framework (Thierfelder, et al., 2007). The model's results may be very sensitive to the assumptions and data used. Almost all CGE exercises include a sensitivity analysis to obtain a range of results based on different assumptions or data. A second problem with CGE analysis is the lack of a time dimension. A CGE analysis of an FTA will not provide results on how long it will take for economies to adjust and reach a new equilibrium. Recent work in CGE modeling has attempted to include some dynamic effects via financial markets; however, but it is a long way from capturing the dynamic features that are most relevant to PTAs. Additionally, it is difficult to model certain non-tariff barriers to trade, such as sanitary, phytosanitary and technical barriers, as also customs issues if these are included in a PTA.

\subsection{Data and Aggregation}

The study makes use of Version 8 of the GTAP database which has been released in 2012. Data on regions and commodities are also aggregated to meet the objectives of this study. Version 8 of the GTAP database covers 57 commodities, 129 regions/countries and 5 factors of production. For the sake of convenience the 129 regions have been aggregated to 13 regions and the 57 commodities have been aggregated into 9 as shown in Annex 1. The 
regions selected include 8 individual South and East Asian countries and 5 other regions which are important trading partner of Bangladesh as well as the EU.

\subsection{Analysis of the Simulation Results: Welfare and Macroeconomic Effects}

We have analyzed four different scenarios. Under Scenario I, elimination of all import tariffs by the EU for Pakistan, under Scenario II, the EU eliminates all tariffs for Pakistan and India (combinedly as one country) and under Scenario III the EU eliminates all tariffs for Pakistan, India and Vietnam (combinedly as one country). We have also tried to explore another scenario: when EU-USA signs FTA, and tried to explore its implications for LDCs.

Table 5.

Scenario I: EU Eliminate Import Tariffs on Pakistan only

\begin{tabular}{|c|c|c|c|c|c|}
\hline Country & $\begin{array}{c}\text { Welfare } \\
\text { Effect (US\$ } \\
\text { million) }\end{array}$ & $\begin{array}{c}\text { \% Change of } \\
\text { Real GDP }\end{array}$ & ToT & $\begin{array}{c}\text { \% Change of } \\
\text { Exports }\end{array}$ & $\begin{array}{c}\text { \% Change of } \\
\text { Imports }\end{array}$ \\
\hline Bangladesh & -11.99 & -0.06 & -0.04 & -0.09 & -0.12 \\
\hline Pakistan & 714.88 & 2.2 & 1.72 & 0.39 & 2.34 \\
\hline India & -11.91 & 0 & 0 & 0.01 & 0 \\
\hline Sri Lanka & -6.13 & -0.04 & -0.03 & 0.01 & -0.06 \\
\hline Viet Nam & 1.85 & 0 & 0.01 & -0.01 & 0 \\
\hline China & -63.79 & 0 & 0 & 0 & 0 \\
\hline Japan & -36.5 & -0.01 & 0 & 0.01 & 0 \\
\hline Korea & -15.52 & -0.01 & 0 & 0 & 0 \\
\hline USA & -129.87 & -0.01 & 0 & 0 & -0.01 \\
\hline Canada & -11.81 & -0.01 & 0 & 0 & 0 \\
\hline RLDCs & -8.81 & 0 & -0.01 & 0 & -0.01 \\
\hline EU_27 & -226.09 & -0.01 & 0 & 0.01 & 0 \\
\hline Rest of World & -141.46 & 0 & 0 & 0 & 0 \\
\hline
\end{tabular}

Source: Author's simulation of GTAP version 8. 
Under Scenario I, if the EU completely eliminates import tariffs, Bangladesh's exports to the EU are expected to drop by about 0.09 percent and the welfare loss equals US \$12 million. Bangladesh would experience a fall in real GDP by 0.06 percent if the EU offers GSP+ to Pakistan to enter the EU market. Other SAARC member countries are affected mildly and a similar impact is observable within LDCs as a whole. The welfare loss of the LDCs could be only US\$8 million. The welfare gain and real GDP of Pakistan could be increased by US\$714 million and 2.2 percent respectively due to preferential tariff by the EU. The table 6 shows the dynamic scenarios of welfare impact of granting GSP plus of Pakistan by the EU. It evinces that Bangladesh real GDP will fall over the years but Pakistan's GDP will be increase significantly by the new trade policy of the EU.

Table 6.

EU Eliminates Import Tariffs on Pakistan (\% Change of Real GDP)

\begin{tabular}{|c|c|c|c|c|c|c|c|c|}
\hline & $\mathbf{2 0 1 5}$ & $\mathbf{2 0 1 6}$ & $\mathbf{2 0 1 7}$ & $\mathbf{2 0 1 8}$ & $\mathbf{2 0 1 9}$ & $\mathbf{2 0 2 0}$ & $\mathbf{2 0 2 1}$ & $\mathbf{2 0 2 2}$ \\
\hline Bangladesh & -0.01 & -0.01 & -0.02 & -0.02 & -0.03 & -0.04 & -0.05 & -0.05 \\
\hline India & 0 & 0 & 0 & 0 & -0.01 & -0.01 & -0.01 & -0.01 \\
\hline Pakistan & 0.13 & 0.27 & 0.46 & 0.67 & 0.89 & 1.13 & 1.38 & 1.6 \\
\hline Vietnam & 0 & -0.01 & -0.01 & -0.01 & -0.02 & -0.02 & -0.02 & -0.02 \\
\hline EU_27 & 0 & 0 & 0 & 0 & 0 & 0 & 0 & 0 \\
\hline ROW & 0 & 0 & 0 & 0 & 0 & 0 & -0.01 & -0.01 \\
\hline
\end{tabular}

Source: Author's simulation of GTAP version 8.

Table 7.

EU Eliminates Import Tariffs on Pakistan (\% Change of Exports of Bangladesh)

\begin{tabular}{|c|c|c|c|c|c|c|c|c|}
\hline & $\mathbf{2 0 1 5}$ & $\mathbf{2 0 1 6}$ & $\mathbf{2 0 1 7}$ & $\mathbf{2 0 1 8}$ & $\mathbf{2 0 1 9}$ & $\mathbf{2 0 2 0}$ & $\mathbf{2 0 2 1}$ & $\mathbf{2 0 2 2}$ \\
\hline Primary & 0.77 & 1.34 & 1.86 & 2.51 & 3.29 & 4.19 & 4.92 & 5.64 \\
\hline $\begin{array}{c}\text { Natural } \\
\text { Resources }\end{array}$ & 0 & 0.01 & 0.03 & 0.06 & 0.1 & 0.15 & 0.21 & 0.28 \\
\hline $\begin{array}{c}\text { Light } \\
\text { Engineering }\end{array}$ & 0.05 & 0.09 & 0.11 & 0.13 & 0.16 & 0.18 & 0.19 & 0.19 \\
\hline $\begin{array}{c}\text { Textile and } \\
\text { Apparel }\end{array}$ & -0.09 & -0.14 & -0.16 & -0.2 & -0.23 & -0.27 & -0.29 & -0.31 \\
\hline
\end{tabular}




\begin{tabular}{|c|c|c|c|c|c|c|c|c|}
\hline & $\mathbf{2 0 1 5}$ & $\mathbf{2 0 1 6}$ & $\mathbf{2 0 1 7}$ & $\mathbf{2 0 1 8}$ & $\mathbf{2 0 1 9}$ & $\mathbf{2 0 2 0}$ & $\mathbf{2 0 2 1}$ & $\mathbf{2 0 2 2}$ \\
\hline $\begin{array}{c}\text { Chemical and } \\
\text { Metal }\end{array}$ & 0.24 & 0.4 & 0.51 & 0.64 & 0.77 & 0.91 & 0.96 & 1 \\
\hline $\begin{array}{c}\text { Machinery and } \\
\text { Equipment }\end{array}$ & 0.16 & 0.27 & 0.34 & 0.42 & 0.51 & 0.61 & 0.64 & 0.67 \\
\hline $\begin{array}{c}\text { Transport and } \\
\text { communication }\end{array}$ & 0.1 & 0.15 & 0.19 & 0.23 & 0.27 & 0.31 & 0.32 & 0.32 \\
\hline $\begin{array}{c}\text { Electronic } \\
\text { equipment }\end{array}$ & 0.04 & 0.11 & 0.18 & 0.27 & 0.38 & 0.49 & 0.56 & 0.61 \\
\hline Service & 0.14 & 0.24 & 0.3 & 0.38 & 0.45 & 0.54 & 0.56 & 0.59 \\
\hline
\end{tabular}

Source: Author's simulation of GTAP version 8.

The table 7 shows the sectotal impact on Bangladesh over the years. The main affecting sector of Bangladesh will be textiles and apparels. The exports of Bangladesh will be reduced at the increasing rate over the period due the Pakistan's free access to the EU market.

Table 8 depicts Scenario II. If the EU offers GSP+ to Pakistan and India gets zero tariffs (either GSP+ or FTA) to enter the EU market then Bangladesh would experience a fall in real GDP of 0.23 percent and welfare lose would be US\$ 48 million. Bangladesh's export could also fall by around 0.17 percent to the EU market. This suggests that if EU offers GSP+ to Pakistan and EU-India signs an FTA, this would give greater market access for Pakistan and India in the EU compared to Bangladesh. Thus the terms of trade of Bangladesh will deteriorate sharply. Export of Bangladesh could also decrease by 0.17 percent.

\section{Table 8.}

The EU Eliminates Import Tariffs on both Pakistan and India

\begin{tabular}{|c|c|c|c|c|c|}
\hline Country & $\begin{array}{c}\text { Welfare } \\
\text { Effect (US\$ } \\
\text { million) }\end{array}$ & $\begin{array}{c}\text { \% Change of } \\
\text { Real GDP }\end{array}$ & ToT & $\begin{array}{c}\text { \% Change of } \\
\text { Exports }\end{array}$ & $\begin{array}{c}\text { \% Change of } \\
\text { Imports }\end{array}$ \\
\hline Bangladesh & -48.38 & -0.23 & -0.2 & -0.17 & -0.34 \\
\hline Pakistan & 675.89 & 2.09 & 1.64 & 0.41 & 2.21 \\
\hline India & 1772.59 & 0.67 & 0.49 & 0.27 & 0.68 \\
\hline Sri Lanka & -24.03 & -0.17 & -0.16 & 0.09 & -0.13 \\
\hline
\end{tabular}




\begin{tabular}{|c|c|c|c|c|c|}
\hline Country & $\begin{array}{c}\text { Welfare } \\
\text { Effect (US\$ } \\
\text { million) }\end{array}$ & $\begin{array}{c}\text { \% Change of } \\
\text { Real GDP }\end{array}$ & ToT & $\begin{array}{c}\text { \% Change of } \\
\text { Exports }\end{array}$ & $\begin{array}{c}\text { \% Change of } \\
\text { Imports }\end{array}$ \\
\hline Viet Nam & -20.72 & -0.05 & -0.02 & -0.03 & -0.06 \\
\hline China & -323.09 & -0.03 & -0.01 & -0.01 & -0.03 \\
\hline Japan & -67.63 & -0.02 & 0 & 0.01 & -0.02 \\
\hline Korea & -38.4 & -0.02 & 0 & 0.01 & -0.02 \\
\hline USA & -238.47 & -0.02 & -0.01 & 0 & -0.02 \\
\hline Canada & -24.03 & -0.01 & 0 & 0 & -0.02 \\
\hline Rest of LDCs & -34.47 & -0.02 & -0.02 & 0 & -0.03 \\
\hline EU_27 & -741.47 & -0.04 & -0.01 & 0.03 & -0.01 \\
\hline Rest of World & -389.93 & -0.02 & 0 & 0 & -0.03 \\
\hline
\end{tabular}

Source: Author's simulation of GTAP version 8.

The table 9 and 10 demonstrate the dynamic scenarios of welfare impact of EU-India FTA. The table shows that Bangladesh's real GDP will fall over the years but Indian gain is obvious under preferential market access by the EU. The textiles and apparels sector of Bangladesh is also main affecting sector. The exports of Bangladesh may be reduced on an average 0.5 percent over the year.

\section{Table 9.}

Effect of EU-India FTA (\% Change of Real GDP)

\begin{tabular}{|c|c|c|c|c|c|c|c|}
\hline & $\mathbf{2 0 1 5}$ & $\mathbf{2 0 1 6}$ & $\mathbf{2 0 1 7}$ & $\mathbf{2 0 1 8}$ & $\mathbf{2 0 1 9}$ & $\mathbf{2 0 2 0}$ & $\mathbf{2 0 2 1}$ \\
\hline Bangladesh & -0.01 & -0.03 & -0.04 & -0.07 & -0.09 & -0.13 & -0.17 \\
\hline India & 0.19 & 0.33 & 0.5 & 0.69 & 0.9 & 1.12 & 1.37 \\
\hline Pakistan & 0 & -0.01 & -0.02 & -0.03 & -0.04 & -0.06 & -0.08 \\
\hline Vietnam & -0.01 & -0.03 & -0.04 & -0.05 & -0.07 & -0.09 & -0.1 \\
\hline EU_28 & 0 & 0 & 0 & -0.01 & -0.01 & -0.02 & -0.02 \\
\hline ROW & 0 & 0 & 0 & -0.01 & -0.01 & -0.01 & -0.02 \\
\hline
\end{tabular}

Source: Author's simulation of GTAP version 8. 
Table 10.

Effect of EU-India FTA on Bangladesh's Exports (\% Change of Export)

\begin{tabular}{|c|c|c|c|c|c|c|c|}
\hline & 2015 & 2016 & 2017 & 2018 & 2019 & 2020 & 2021 \\
\hline Primary & 0.24 & 0.43 & 0.63 & 0.87 & 1.16 & 1.49 & 1.84 \\
\hline Natural Resources & -4.41 & -6.67 & -7.4 & -7.98 & -8.41 & -8.73 & -7.49 \\
\hline Light Engineering & 0.24 & 0.43 & 0.59 & 0.79 & 1.02 & 1.29 & 1.45 \\
\hline Textile and Apparel & -0.12 & -0.21 & -0.3 & -0.39 & -0.5 & -0.63 & -0.71 \\
\hline Chemical and Metal & 0.74 & 1.35 & 1.87 & 2.49 & 3.26 & 4.14 & 4.65 \\
\hline $\begin{array}{c}\text { Machinery and } \\
\text { Equipment }\end{array}$ & 0.42 & 0.79 & 1.1 & 1.5 & 2 & 2.58 & 2.94 \\
\hline $\begin{array}{l}\text { Transport and } \\
\text { communication }\end{array}$ & -1.07 & -1.65 & -1.94 & -2.26 & -2.63 & -3.04 & -3.08 \\
\hline $\begin{array}{l}\text { Electronic } \\
\text { equipment }\end{array}$ & -0.36 & -0.2 & 0.15 & 0.61 & 1.2 & 1.87 & 2.4 \\
\hline Service & 0.48 & 0.85 & 1.14 & 1.48 & 1.91 & 2.39 & 2.65 \\
\hline
\end{tabular}

Source: Author's simulation of GTAP version 8.

Table 11 shows Scenario III where the EU eliminates all tariffs for Pakistan, India and Vietnam. If the EU cuts all tariffs for these countries, Bangladesh's real GDP will decrease by about 0.27 percent and the welfare losses could be US\$ 54 million. Total exports to the EU may be reduced by 0.18 percent sharply reducing Bangladesh's terms of trade. The welfare gains of Pakistan, India and Vietnam could be to the tune of US\$ 674 million, 1748 million and US\$ 898 million; the real GDP could rise by 2.10, 0.67 and 2.46 percent respectively. The main competitors of Bangladesh in the EU market could be Pakistan, India and Vietnam thanks to the duty free treatment they would enjoy in the EU under $\mathrm{GSP}+$ scheme or as a result of signing of FTA(s). 
Table 11.

EU Eliminates Import Tariffs on Pakistan, India and Vietnam

\begin{tabular}{|c|c|c|c|c|c|}
\hline Country & $\begin{array}{c}\text { Welfare Effect } \\
\text { (US\$ million) }\end{array}$ & $\begin{array}{c}\text { \% Change of } \\
\text { Real GDP }\end{array}$ & ToT & $\begin{array}{c}\text { \% Change of } \\
\text { Exports }\end{array}$ & $\begin{array}{c}\text { \% Change of } \\
\text { Imports }\end{array}$ \\
\hline Bangladesh & -54.11 & -0.27 & -0.23 & -0.18 & -0.46 \\
\hline Pakistan & 673.88 & 2.09 & 1.63 & 0.41 & 2.19 \\
\hline India & 1747.83 & 0.67 & 0.48 & 0.27 & 0.69 \\
\hline Sri Lanka & -25.97 & -0.19 & -0.17 & 0.11 & -0.23 \\
\hline Viet Nam & 897.58 & 2.46 & 0.89 & 0.89 & 2.36 \\
\hline China & -407.64 & -0.03 & -0.02 & -0.01 & -0.02 \\
\hline Japan & -150.35 & -0.02 & -0.01 & 0.02 & -0.02 \\
\hline Korea & -30.7 & -0.01 & 0 & 0.01 & 0 \\
\hline USA & -372.77 & -0.02 & -0.01 & 0 & -0.02 \\
\hline Canada & -24.41 & -0.01 & 0 & 0 & -0.01 \\
\hline RLDCs & -36.1 & -0.02 & -0.02 & -0.01 & -0.04 \\
\hline EU_27 & -1093.26 & -0.06 & -0.02 & 0.05 & 0.02 \\
\hline Rest of World & -353.44 & -0.02 & 0 & -0.01 & -0.02 \\
\hline
\end{tabular}

Source: Author's simulation of GTAP version 8.

The dynamic welfare impact of EU-Vietnam presents in the table 12 and table 13. It shows that Bangladesh real GDP may fall but not in a substantial manner. However, Bangladesh's exports of readymade garments could be reduced. Vietnam may gain significantly from signing a FTA with the EU.

Table 12.

Economic Effect of EU-Vietnam FTA (\% Change of Real GDP)

\begin{tabular}{|c|c|c|c|c|c|c|c|c|}
\hline & $\mathbf{2 0 1 5}$ & $\mathbf{2 0 1 6}$ & $\mathbf{2 0 1 7}$ & $\mathbf{2 0 1 8}$ & $\mathbf{2 0 1 9}$ & $\mathbf{2 0 2 0}$ & $\mathbf{2 0 2 1}$ & $\mathbf{2 0 2 2}$ \\
\hline Bangladesh & 0 & -0.01 & -0.01 & -0.02 & -0.02 & -0.03 & -0.04 & -0.04 \\
\hline India & 0 & 0 & -0.01 & -0.01 & -0.01 & -0.02 & -0.02 & -0.02 \\
\hline Pakistan & 0 & -0.01 & -0.01 & -0.01 & -0.02 & -0.02 & -0.03 & -0.03 \\
\hline Vietnam & 0.51 & 0.83 & 1.1 & 1.35 & 1.56 & 1.72 & 1.82 & 1.85 \\
\hline EU_27 & 0 & 0 & 0 & 0 & 0 & 0 & 0 & 0 \\
\hline ROW & 0 & 0 & 0 & 0 & 0 & 0 & 0 & -0.01 \\
\hline
\end{tabular}

Source: Author's simulation of GTAP version 8. 
Table 13.

Effect of EU-Vietnam FTA on Bangladesh's Export (\% Change of exports)

\begin{tabular}{|c|c|c|c|c|c|c|c|c|}
\hline & $\mathbf{2 0 1 5}$ & $\mathbf{2 0 1 6}$ & $\mathbf{2 0 1 7}$ & $\mathbf{2 0 1 8}$ & $\mathbf{2 0 1 9}$ & $\mathbf{2 0 2 0}$ & $\mathbf{2 0 2 1}$ & $\mathbf{2 0 2 2}$ \\
\hline Primary & 0.09 & 0.15 & 0.18 & 0.22 & 0.26 & 0.3 & 0.31 & 0.31 \\
\hline $\begin{array}{c}\text { Natural } \\
\text { Resources }\end{array}$ & 0.15 & 0.23 & 0.29 & 0.35 & 0.42 & 0.48 & 0.5 & 0.51 \\
\hline $\begin{array}{c}\text { Light } \\
\text { Engineering }\end{array}$ & 0.14 & 0.23 & 0.28 & 0.34 & 0.4 & 0.46 & 0.45 & 0.44 \\
\hline $\begin{array}{c}\text { Textile and } \\
\text { Apparel }\end{array}$ & -0.04 & -0.07 & -0.08 & -0.09 & -0.11 & -0.13 & -0.15 & -0.16 \\
\hline $\begin{array}{c}\text { Chemical and } \\
\text { Metal }\end{array}$ & 0.32 & 0.52 & 0.63 & 0.73 & 0.82 & 0.9 & 0.83 & 0.74 \\
\hline $\begin{array}{c}\text { Machinery and } \\
\text { Equipment }\end{array}$ & 0.22 & 0.35 & 0.43 & 0.51 & 0.58 & 0.64 & 0.6 & 0.54 \\
\hline $\begin{array}{c}\text { Transport and } \\
\text { communication }\end{array}$ & 0.14 & 0.22 & 0.26 & 0.3 & 0.33 & 0.35 & 0.32 & 0.28 \\
\hline $\begin{array}{c}\text { Electronic } \\
\text { equipment }\end{array}$ & 0.29 & 0.48 & 0.58 & 0.67 & 0.76 & 0.83 & 0.76 & 0.68 \\
\hline \begin{tabular}{c} 
Service \\
\hline
\end{tabular} & 0.18 & 0.29 & 0.36 & 0.42 & 0.47 & 0.52 & 0.49 & 0.45 \\
\hline
\end{tabular}

Source: Author's simulation of GTAP version 8.

Then we have tried to explore the economic impact of EU-USA FTA on Bangladesh. The table 14 shows the macroeconomic impact of the proposed FTA between EU and USA which might be signing an agreement in the end of 2016.10) The trade between EU-US could be boosted due to tariff elimination. Bilateral trade will also accelerate by relaxed non-tariff barriers as well as increased regulatory harmonization and compatibility between two countries. A US-EU FTA is expected to bring LDCs real GDP down by 0.1 percent and welfare levels down by US\$ 36 million. The table also shows that Bangladesh's real GDP could be minuscule down by 0.2 percent and welfare losses might be about US\$ 21 million but overall exports to the EU may not decreased for the FTA.

10) Within the US president's current term of office (end of 2016) 
Table 14.

Impact of Proposed EU-USA FTA on LDCs

\begin{tabular}{|c|c|c|c|c|c|}
\hline Country & $\begin{array}{c}\text { Welfare Effect } \\
\text { (US\$ million) }\end{array}$ & $\begin{array}{c}\text { \% Change of } \\
\text { Real GDP }\end{array}$ & ToT & $\begin{array}{c}\text { \% Change of } \\
\text { Exports }\end{array}$ & $\begin{array}{c}\text { \% Change of } \\
\text { Imports }\end{array}$ \\
\hline Bangladesh & -21.1 & -0.2 & -0.08 & 0.03 & -0.14 \\
\hline Pakistan & -40.46 & -0.18 & -0.1 & 0.09 & -0.14 \\
\hline India & -259.17 & -0.11 & -0.04 & 0.02 & -0.09 \\
\hline Sri Lanka & -14.5 & -0.21 & -0.1 & 0.11 & -0.12 \\
\hline Viet Nam & -47.97 & -0.19 & -0.04 & -0.03 & -0.12 \\
\hline China & -1038.21 & -0.13 & -0.04 & 0.01 & -0.05 \\
\hline Japan & -601.17 & -0.12 & -0.06 & 0.11 & -0.11 \\
\hline Korea & -260.43 & -0.11 & -0.04 & 0.02 & -0.07 \\
\hline USA & 5517.9 & 0.19 & 0.22 & 0.99 & 0.97 \\
\hline Canada & -708.81 & -0.17 & -0.14 & -0.04 & -0.3 \\
\hline R LDCs & -36.52 & -0.1 & -0.01 & -0.01 & -0.08 \\
\hline EU_27 & 1760.14 & 0.14 & 0 & 0.93 & 0.14 \\
\hline Rest of World & -2090.84 & -0.1 & -0.03 & 0 & -0.09 \\
\hline
\end{tabular}

Source: Author's simulation of GTAP version 8.

The above four scenario analysis indicates how individual sectors perform in terms of exports at the bilateral level with the abolition of import duties by the EU. For both LDCs and Bangladesh, the magnitudes of change in export volumes result in similar outcomes under the four scenarios and will reduce exports both by LDCs and Bangladesh to the EU market. Textiles and clothing export could be come down under all four scenarios. This would amply that Bangladesh is one of the major losers as consequence of new tariff policy of EU particularly for the textiles and clothing sector. 


\section{Disaggregate Analysis: The Case of Bangladesh}

\subsection{Possible Affected Export Items of Bangladesh to the EU if Pakistan gets GSP+}

Bangladesh's main export sectors to the EU are articles of apparel and clothing accessories under HS 61 and under HS 62. These two sectors constitute almost 88 percent of EU imports from Bangladesh in 2011. Bangladesh has zero tariffs in the EU market whereas Pakistan has tariff rates of more than 9 percent of these sectors. The EU also imports around US\$ 2 billion of these two sectors from Pakistan. Thus, if Pakistan gets zero tariff access for products under GSP+ then exports from Pakistan will increase enormously and Bangladesh's exports of these products would be diverted to Pakistan.

Table 15 shows the Revealed Comparative Advantages (RCA) ${ }^{11)}$ and unit price of these sectors for Bangladesh and Pakistan. The competitive position of these two sectors is very close and Pakistan has competitive position on Bangladesh's top export sectors to the EU. On textile products under HS 63 even paying about around 9 percent tariff, Pakistan is exporting more than Bangladesh. On other items under HS 41, 42, 08, 57 etc. Pakistan is exporting much more than Bangladesh even with a tariff whereas Bangladesh faces a zero tariff. These sectors will be much more affected once Pakistan gets GSP+.

\section{Table-15.}

Possible Affected Export Items of Bangladesh to EU if Pakistan Gets GSP+

US\$ million

\begin{tabular}{|c|c|c|c|c|c|c|c|c|c|}
\hline \multirow{2}{*}{ Code } & \multirow{2}{*}{ Product Name } & \multicolumn{2}{|c|}{ Import by EU in 2011 } & \multicolumn{2}{c|}{$\begin{array}{c}\text { Applied Tariff } \\
\text { by EU in 2011 }\end{array}$} & \multicolumn{2}{c|}{ RCA 2011 } & \multicolumn{2}{|c|}{$\begin{array}{c}\text { Unit Price } \\
\text { (Euro/100kg) }\end{array}$} \\
\cline { 3 - 10 } & Bangladesh & Pakistan & BD & Pak & BD & Pak & BD & Pak \\
\hline 610910 & $\begin{array}{c}\text { T-shirts, } \\
\text { singlets \& }\end{array}$ & $2,688.52$ & 78.76 & 0 & 9.60 & 0.98 & 0.76 & 1018 & 1023 \\
\hline
\end{tabular}

11) The RCA indicator, commonly known as the Balassa index, is calculated using the following equation:

$R C A_{i w}^{k}=\left(\frac{x_{i w}^{k}}{X_{i w}}\right) \div\left(\frac{x_{w w}^{k}}{X_{w w}}\right)$

Where $k$ is a commodity, $i$ is Bangladesh, and $w$ is world. The index compares the share of exports of Bangladesh of a given product, with the share of exports of that product in world exports. If a country exports proportionately more than the level of exports in the world, than the country is said to have a "revealed" comparative advantage in that product.

The numbers presented in the table are normalised so that they lie within the interval -1 to 1 . Positive values identify comparative advantages and negatives values capture comparative disadvantages. 


\begin{tabular}{|c|c|c|c|c|c|c|c|c|c|}
\hline \multirow{2}{*}{ Code } & \multirow{2}{*}{ Product Name } & \multicolumn{2}{|c|}{ Import by EU in 2011} & \multicolumn{2}{|c|}{$\begin{array}{l}\text { Applied Tariff } \\
\text { by EU in } 2011\end{array}$} & \multicolumn{2}{|c|}{ RCA 2011} & \multicolumn{2}{|c|}{$\begin{array}{c}\text { Unit Price } \\
\text { (Euro/100kg) }\end{array}$} \\
\hline & & Bangladesh & Pakistan & BD & Pak & BD & Pak & BD & Pak \\
\hline 620342 & Men's/boys' & $1,305.93$ & 546.98 & 0 & 9.6 & 0.98 & 0.91 & 1254 & 1262 \\
\hline 611020 & $\begin{array}{l}\text { Jerseys, } \\
\text { pullovers, }\end{array}$ & $1,206.72$ & 114.66 & 0 & 9.60 & 0.97 & 0.15 & 1351 & 937 \\
\hline 611030 & $\begin{array}{l}\text { Jerseys, } \\
\text { pullovers, }\end{array}$ & 924.69 & 21.65 & 0 & 9.60 & 0.96 & -0.73 & 1193 & 637 \\
\hline 620462 & Women's/girls', & 644.16 & 209.88 & 0 & 9.6 & 0.97 & 0.88 & 1326 & 1489 \\
\hline 610510 & $\begin{array}{l}\text { Men's/boys' } \\
\text { shirts, }\end{array}$ & 532.22 & 62.35 & 0 & 9.6 & 0.98 & 0.95 & 1120 & 1285 \\
\hline 610462 & Women's/girls' & 290.47 & 39.11 & 0 & 9.6 & 0.96 & 0.66 & 1076 & 1007 \\
\hline 611120 & $\begin{array}{c}\text { Babies' } \\
\text { garments \& }\end{array}$ & 195.89 & 9.02 & 0 & 8.35 & 0.75 & 0.41 & 1497 & 1251 \\
\hline 610610 & $\begin{array}{c}\text { Women's/girls' } \\
\text { blouses, shirts } \\
\&\end{array}$ & 175.48 & 8.38 & 0 & 9.6 & 0.96 & 0.79 & 1319 & 945 \\
\hline 630221 & Bed linen (excl. & 153.85 & 309.51 & 0 & 9.6 & 0.97 & 0.90 & 627 & 639 \\
\hline 630231 & $\begin{array}{l}\text { Bed linen (excl. } \\
\text { knitted/crochet } \\
\text { ed), }\end{array}$ & 111.62 & 320.95 & 0 & 9.6 & 0.93 & 0.99 & 708 & 599 \\
\hline
\end{tabular}

Source: Author's Calculation from WITS, by using TradeSift (V2.0) and EUSTAT

The unit export price of Bangladesh and Pakistan in the EU market has also been presented in table 15. It shows that the export unit price of major export items of Bangladesh to the EU are very close to or even lower than Pakistan's unit price in the EU market. These products will certainly face difficulties in exporting into the EU market from January 2014 since Pakistan already receives GSP plus treatment in the EU market. The products under HS code 63 will face the most difficulties to enter EU market from January 2014. 


\subsection{Possible Affected Export Items of Bangladesh to EU if India Gets Zero Tariffs}

As India is a very strong competitor for Bangladesh in the EU market, the agreement could displace Bangladeshi exports. Bangladesh enjoys EBA preference in the EU market, but in Bangladesh's top export items to the EU India, on an average, has about 9.6 percent tariff (preferential tariff under GSP for developing countries) giving Bangladesh a preference margin of 9.6 percent. If India gets duty free access under the FTA agreement, Bangladesh will lose this preference margin. This could have serious adverse impact for Bangladesh's exports to the EU.

From Table 16, it is seen that all Bangladesh's top export items to the EU have a comparative advantage. India also has a comparative advantage on most of Bangladesh's top export items to the EU except for jerseys, pullovers, cardigans etc. of man-made fibres, knit under HS 611030. India's comparative advantage on products under HS 611020 and HS 620342 is very low, which mean even if India receives a zero tariff benefit under the FTA agreement, India might not be able to compete with Bangladesh since Bangladesh has a better comparative advantage on these products.

Unit export prices of Bangladesh and India to the EU market are presented in Table 16. It shows that the export unit prices of major export items of Bangladesh to EU are lower compared to India's unit price in the EU market. Although India export unit price is higher compared to Bangladesh, their exports to the EU is also high which implies that demand for Indian products and the quality would be higher for these products.

Table 16.

Top 10 'Affected' if India Gets Zero Tariff

\begin{tabular}{|c|c|c|c|c|c|c|c|c|}
\hline \multirow{2}{*}{ Product } & \multirow{2}{*}{ Product Name } & \multicolumn{2}{|c|}{ Bangladesh } & \multicolumn{3}{c|}{ India } & \multicolumn{2}{|c|}{$\begin{array}{c}\text { Unit Price } \\
\text { (Euro/100kg) }\end{array}$} \\
\cline { 3 - 10 } & $\begin{array}{c}\text { Export } \\
\text { Value }\end{array}$ & RCA & $\begin{array}{c}\text { EU } \\
\text { Tariff }\end{array}$ & $\begin{array}{c}\text { Export } \\
\text { Value }\end{array}$ & RCA & BD & India \\
\hline 610910 & $\begin{array}{c}\text { T-shirts, singlets \& } \\
\text { other vests, }\end{array}$ & $2,664.25$ & 0.98 & 9.6 & $1,023.4$ & 0.65 & 1018 & 1718 \\
\hline 611020 & $\begin{array}{c}\text { Jerseys, pullovers, } \\
\text { cardigans, waist-coats }\end{array}$ & $1,304.39$ & 0.97 & 9.6 & 248.75 & 0.31 & 1351 & 1795 \\
\hline 620342 & $\begin{array}{c}\text { Men's/boys' trousers, } \\
\text { bib \& brace overalls, }\end{array}$ & $1,177.52$ & 0.98 & 9.6 & 227.29 & 0.16 & 1254 & 1896 \\
\hline 611030 & $\begin{array}{c}\text { Jerseys, pullovers, } \\
\text { cardigans, waist-coats }\end{array}$ & 800.14 & 0.96 & 9.6 & 40.02 & -0.54 & 1193 & 1560 \\
\hline
\end{tabular}




\begin{tabular}{|c|c|c|c|c|c|c|c|c|}
\hline \multirow{2}{*}{ Product } & \multirow{2}{*}{ Product Name } & \multicolumn{2}{|c|}{ Bangladesh } & \multicolumn{3}{c|}{ India } & \multicolumn{2}{|c|}{$\begin{array}{c}\text { Unit Price } \\
\text { (Euro/100kg) }\end{array}$} \\
\cline { 3 - 10 } & $\begin{array}{c}\text { Export } \\
\text { Value }\end{array}$ & RCA & $\begin{array}{c}\text { EU } \\
\text { Tariff }\end{array}$ & $\begin{array}{c}\text { Export } \\
\text { Value }\end{array}$ & RCA & BD & India \\
\hline 620462 & $\begin{array}{c}\text { Women's/girls', } \\
\text { trousers, bib \& brace }\end{array}$ & 560.77 & 0.96 & 9.6 & 153.61 & 0.12 & 1326 & 2208 \\
\hline 610510 & $\begin{array}{c}\text { Men's/boys' shirts, } \\
\text { knitted/crocheted }\end{array}$ & 432.95 & 0.97 & 9.6 & 219.64 & 0.70 & 1120 & 1807 \\
\hline 620520 & $\begin{array}{c}\text { Men's/boys' shirts } \\
\text { (excl. } \\
\text { knitted/crocheted) }\end{array}$ & 421.22 & 0.97 & 9.6 & 470.32 & 0.67 & - & - \\
\hline 60613 & $\begin{array}{c}\text { Shrimps \& prawns, } \\
\text { whether/not in shell, } \\
\text { frozen }\end{array}$ & 303.33 & 0.93 & 4.2 & 340.18 & 0.70 & - & - \\
\hline 610462 & $\begin{array}{c}\text { Women's/girls' } \\
\text { trousers, bib \& brace }\end{array}$ & 78.75 & 0.96 & 9.6 & 135.17 & 0.41 & 1076 & 1444 \\
\hline 611120 & $\begin{array}{c}\text { Babies garments, } \\
\text { accessories }\end{array}$ & 184.52 & 0.95 & 8.3 & 220.68 & 0.65 & 1497 & 1881 \\
\hline
\end{tabular}

Source: Author's Calculation from WITS, by using TradeSift (V2.0) and EUSTAT

\subsection{Possible Affected Export Items of Bangladesh to EU if Vietnam gets Zero Tariffs}

Table 17 identifies the top 10 affected products by using RCA and unit price. A number of observations can be made. Firstly, Vietnam has lower comparative advantage in all of the top products. Secondly, export share and market share in the EU are comparatively low. Thirdly, preference margin that Bangladesh currently has in the EU is about 12 percent. The fourthly, unit prices of the most of these products are much higher of Vietnam compared to Bangladesh in the EU market.

With all of this in mind, it seems that Vietnam is not a strong competitor to Bangladeshi exports to the EU, but it is worth highlighting that this result may be driven by the current preferences offered to Bangladesh. Vietnam certainly has the potential to displace Bangladeshi exports should it have the same preferences that Bangladesh does in the EU market. 
Table 17.

Possible Affected Export Items of Bangladesh to EU if Vietnam Gets Zero Tariffs

\begin{tabular}{|c|c|c|c|c|c|c|c|c|}
\hline \multirow{2}{*}{ Product } & \multirow{2}{*}{ Product Name } & \multicolumn{2}{|c|}{ Bangladesh } & \multicolumn{3}{|c|}{ India } & \multicolumn{2}{|c|}{$\begin{array}{c}\text { Unit Price } \\
\text { (Euro/100kg) }\end{array}$} \\
\hline & & $\begin{array}{l}\text { Export } \\
\text { Value }\end{array}$ & RCA & $\begin{array}{c}\text { EU } \\
\text { Tariff }\end{array}$ & $\begin{array}{l}\text { Export } \\
\text { Value }\end{array}$ & RCA & BD & India \\
\hline 610910 & $\begin{array}{l}\text { T-shirts, } \\
\text { singlets \& }\end{array}$ & 24.11 & 0.98 & 12.00 & 0.42 & 0.57 & 1018 & 1233 \\
\hline 611020 & $\begin{array}{l}\text { Jerseys, } \\
\text { pullovers, }\end{array}$ & 11.80 & 0.97 & 12.00 & 0.42 & 0.82 & 1351 & 1661 \\
\hline 620342 & $\begin{array}{l}\text { Men's/boys' } \\
\text { trousers, }\end{array}$ & 10.65 & 0.98 & 12.00 & 0.56 & 0.64 & 1254 & 1566 \\
\hline 611030 & $\begin{array}{l}\text { Jerseys, } \\
\text { pullovers, }\end{array}$ & 7.24 & 0.96 & 12.00 & 0.71 & 0.72 & 1193 & 1333 \\
\hline 620462 & $\begin{array}{l}\text { Women's/girls', } \\
\text { trousers, bib \& } \\
\text { brace }\end{array}$ & 5.07 & 0.96 & 12.00 & 0.54 & 0.73 & 1326 & 1406 \\
\hline 610510 & $\begin{array}{l}\text { Men's/boys' } \\
\text { shirts, }\end{array}$ & 3.92 & 0.97 & 12.00 & 0.23 & 0.81 & 1120 & 1451 \\
\hline 620520 & $\begin{array}{l}\text { Men's/boys' } \\
\text { shirts }\end{array}$ & 3.81 & 0.97 & 12.00 & 0.98 & 0.77 & - & - \\
\hline 30613 & $\begin{array}{c}\text { Shrimps \& } \\
\text { prawns, } \\
\text { whether/not in } \\
\text { shell, }\end{array}$ & 2.74 & 0.93 & 5.92 & 1.49 & 0.92 & - & - \\
\hline 610462 & Women's/girls' & 2.52 & 0.96 & 12.00 & 0.23 & 0.84 & 1076 & 1216 \\
\hline 611120 & $\begin{array}{c}\text { Babies } \\
\text { garments, }\end{array}$ & 1.67 & 0.95 & 10.45 & 0.04 & 0.41 & 1497 & 2700 \\
\hline
\end{tabular}

Source: Author's Calculation from WITS, by using TradeSift (V2.0) and EUSTAT

Table 18 shows export share, tariff and Revealed Comparative Advantages (RCA) of these sectors for Bangladesh and the majority of the ASEAN countries. It is seen that all Bangladesh's top export items to the EU enjoy a comparative advantage. Indonesia, Thailand and Cambodia also have comparative advantage of some products on Bangladesh's top export items to the EU. Myanmar is also not a strong competitor of 
Bangladesh at this moment in the EU market as they have to pay 12 percent tariff but recently EU has granted EBA facilities to Myanmar. This scenario could be change as they have been exporting Men's/boys' shirts (excl. knitted/crocheted), and Men's/boys' trousers. Indonesia could be very strong competitor of Men's/boys' shirts (620520) and shrimp and prawn (030613) as they have strong comparative advantages of these two items in the EU market. Thailand has very strong comparative advantages of shrimp and prawn (030613) as well. If ASEAN-EU signs FTA the most affected sector will be shrimp and prawn (030613) in addition textiles and clothing.

\section{Table 18.}

Possible Affected Export Items of Bangladesh to EU if ASEAN sign FTA with EU

(US\$ million, 2011)

\begin{tabular}{|c|c|c|c|c|c|c|c|c|c|c|}
\hline \multirow{2}{*}{ Code } & \multicolumn{2}{|c|}{ Bangladesh } & \multicolumn{3}{c|}{ Indonesia } & \multicolumn{2}{c|}{ Thailand } & \multicolumn{3}{c|}{ Cambodia } \\
\cline { 2 - 12 } & $\begin{array}{c}\text { Import by } \\
\text { EU }\end{array}$ & RCA & Import & Tariff & RCA & Import & Tarif & RCA & Import & RCA \\
\hline 610910 & $2,664.25$ & 0.98 & 70.06 & 9.60 & 0.05 & 37.60 & 9.60 & -0.31 & 96.96 & 0.9 \\
\hline 611020 & $1,304.39$ & 0.97 & 90.50 & 9.60 & 0.51 & 41.26 & 9.60 & -0.52 & 251.54 & 0.86 \\
\hline 620342 & $1,177.52$ & 0.98 & 96.10 & 9.60 & 0.09 & 44.94 & 9.60 & -0.48 & 41.92 & 0.27 \\
\hline 611030 & 800.14 & 0.96 & 85.05 & 9.60 & 0.02 & 104.11 & 9.60 & -0.27 & 204.31 & -0.75 \\
\hline 620462 & 560.77 & 0.96 & 48.92 & 9.60 & 0.07 & 18.48 & 9.60 & -0.70 & 39.84 & 0.26 \\
\hline 610510 & 432.95 & 0.97 & 26.22 & 9.60 & 0.27 & 23.45 & 9.60 & 0.07 & 37.50 & 0.82 \\
\hline 620520 & 421.22 & 0.97 & 138.53 & 9.60 & 0.58 & 27.59 & 9.60 & -0.11 & 18.93 & -0.49 \\
\hline 30613 & 303.33 & 0.93 & 90.98 & 5.92 & 0.73 & 266.33 & 5.92 & 0.81 & - & - \\
\hline 610462 & 78.75 & 0.96 & 25.36 & 9.60 & 0.44 & 4.42 & 9.60 & -0.67 & 54.21 & 0.95 \\
\hline 611120 & 184.52 & 0.95 & 20.78 & 8.35 & -0.01 & 27.33 & 8.35 & 0.50 & 16.09 & 0.66 \\
\hline
\end{tabular}

Source: BACI, Indicators calculated using TradeSift 
Table 19.

Possible Affected Export Items of Bangladesh to EU if USA signs FTA with EU

\begin{tabular}{|c|c|c|c|c|c|c|}
\hline \multirow[b]{2}{*}{ Code } & \multirow[b]{2}{*}{$\begin{array}{l}\text { Product } \\
\text { Description }\end{array}$} & \multicolumn{2}{|c|}{ Bangladesh } & \multicolumn{3}{|c|}{ USA } \\
\hline & & $\begin{array}{c}\text { Export in } \\
2012 \\
\text { (US\$ mil) }\end{array}$ & RCA & $\begin{array}{c}\text { Export in } \\
2012 \\
\text { (US\$ mil) }\end{array}$ & Tariff & RCA \\
\hline 030613 & $\begin{array}{l}\text { Frozen shrimps } \\
\text { and prawns }\end{array}$ & 329.55 & 0.92 & 30.79 & - & -0.87 \\
\hline 610442 & $\begin{array}{l}\text { Dresses of cotton, } \\
\text { knitted or }\end{array}$ & 111.26 & 0.77 & 2.94 & 12 & -0.95 \\
\hline 610462 & $\begin{array}{l}\text { Women's or girls' } \\
\text { trousers, etc, }\end{array}$ & 405.54 & 0.95 & 4.37 & 12 & -0.92 \\
\hline 610510 & $\begin{array}{l}\text { Men's or boys' } \\
\text { shirts of cotton, }\end{array}$ & 561.5 & 0.98 & 4.96 & 12 & -0.81 \\
\hline 610610 & $\begin{array}{l}\text { Women's or girls' } \\
\text { blouses, etc, }\end{array}$ & 206.33 & 0.97 & 3.25 & 12 & -0.81 \\
\hline 610910 & $\begin{array}{l}\text { T-shirts, singlets } \\
\text { and other }\end{array}$ & 3154.94 & 0.98 & 57.24 & 12 & -0.77 \\
\hline 610990 & $\begin{array}{l}\text { T-shirts, singlets, } \\
\text { etc, of other }\end{array}$ & 166.03 & 0.87 & 30.31 & 12 & -0.81 \\
\hline 611010 & $\begin{array}{l}\text { Jerseys, pullovers, } \\
\text { etc, of wool }\end{array}$ & 112.19 & 0.89 & 2.54 & 11.5 & -0.91 \\
\hline 611020 & $\begin{array}{l}\text { Jerseys, pullovers, } \\
\text { etc, of }\end{array}$ & 1357.29 & 0.97 & 13.37 & 12 & -0.87 \\
\hline 611030 & $\begin{array}{l}\text { Jerseys, pullovers, } \\
\text { etc, }\end{array}$ & 965.93 & 0.96 & 7.39 & 12 & -0.87 \\
\hline 611120 & $\begin{array}{l}\text { Babies' garments, } \\
\text { etc, }\end{array}$ & 267.26 & 0.97 & 2.75 & 10.45 & -0.85 \\
\hline 620342 & $\begin{array}{l}\text { Men's or boys' } \\
\text { trousers, }\end{array}$ & 1956.98 & 0.98 & 18.58 & 12 & -0.8 \\
\hline 620343 & $\begin{array}{l}\text { Men's or boys' } \\
\text { trousers, }\end{array}$ & 116.53 & 0.95 & 0.96 & 12 & -0.65 \\
\hline 620462 & $\begin{array}{l}\text { Women's or girls' } \\
\text { trousers, }\end{array}$ & 1112.7 & 0.97 & 66.01 & 12 & -0.76 \\
\hline 620520 & $\begin{array}{l}\text { Men's or boys' } \\
\text { shirts of cotton }\end{array}$ & 704.19 & 0.98 & 4.19 & 12 & -0.88 \\
\hline 620530 & $\begin{array}{l}\text { Men's or boys' } \\
\text { shirts of man- }\end{array}$ & 174 & 0.98 & 0.34 & 12 & -0.69 \\
\hline 620630 & $\begin{array}{c}\text { Women's or girls' } \\
\text { blouses, }\end{array}$ & 168.25 & 0.96 & 1.32 & 12 & -0.86 \\
\hline 620920 & $\begin{array}{l}\text { Bables' garments } \\
\text { and clothing }\end{array}$ & 152.33 & 0.99 & 0.72 & 10.5 & -0.87 \\
\hline 630221 & $\begin{array}{l}\text { Printed bed-linen } \\
\text { of cotton }\end{array}$ & 124.36 & 0.96 & 0.14 & 12 & -0.87 \\
\hline 630231 & $\begin{array}{l}\text { Bed linen of cotton } \\
\text { (excl. }\end{array}$ & 111 & 0.92 & 0.71 & 12 & -0.76 \\
\hline
\end{tabular}

Source: Data collected from WITS and Mirror Data accessed on 17/12/2013 
Table 19 shows the tariff structure of top 20 exports of Bangladesh to the EU and their RCA. The analysis reveals that Bangladesh has revealed comparative advantage to the EU with MFN tariffs between 10 and 12 percent versus the US in top twenty products to the EU. The USA does not have any revealed comparative advantage of these items. This suggests that USA producers will have difficulty in exploiting the benefits of the abolition of MFN tariffs in these categories on the EU market.

\section{Conclusions and Policy Recommendations:}

Bangladesh exported US\$ 13.7 billion worth of goods to the EU in 2011. The average growth of exports to the EU between 2007 and 2011 was 13.8 percent. Although, EU sources only 0.5 percent of its imports from Bangladesh, it is a destination for more than 58 percent of Bangladesh's exports. On the other hand, total exports from Pakistan, India and Vietnam were US\$ 81.21 billion in 2011. Moreover, EU-USA are the biggest trading partner in the world. The total trade between USA-EU was US\$ 676 billion in 2012 where EU's exports' to the USA was about US\$ 400 billion.

The EU is the most important export market for Bangladesh. Bangladesh receives duty free access for all her exported products (under the EBA scheme). Under the new regime, GSP+ beneficiaries will likely compete on the same footing with Bangladesh in almost all tariff lines. For example, Pakistan could be a strong competitor since she will receive duty free treatment for exports to the $\mathrm{EU}$ under the GSP+ scheme as the EU parliament has approved GSP plus scheme for Pakistan on November 5, 2013. The EU is also trying to conclude FTAs with many developing countries including India, Vietnam, Malaysia, Singapore, Indonesia and others. As the estimates indicate, if the EU eliminates all tariffs for Pakistan, India and Vietnam, Bangladesh's real GDP may fall by 0.27 percent and the welfare losses could be US\$ 54 million. Total exports to the EU could be reduced by 0.18 percent, resulting in significant deterioration in Bangladesh's terms of trade. The welfare gain of Pakistan, India and Vietnam will be US\$ 674 million, 1748 million and US\$ 898 million. Their real GDP could be increased by $2.10,0.67$ and 2.46 percent respectively. These countries will compete with LDCs, particularly with Bangladesh, in products such as textiles and clothing, frozen foods, leather goods and agricultural products. The RCA and unit price of these items also indicates that these products will face formidable difficulties in entering the EU market. This implies that Bangladesh should keep a watchful eye on EU's new preferential trading arraignments since there is a strong potential for new 
preferential partners to receive equal preferences. This could potentially displace Bangladeshi exports. On the other hand, due to EU-USA FTA, Bangladesh's real GDP could be down by 0.2 percent and welfare loss could be about US\$ 21 million. But the analysis presented in this paper indicates that Bangladesh has Revealed Comparative Advantage in the EU where MFN tariffs vary between 10 and 12 percent, vis-a-vis US for top twenty products to the EU. This suggests that US producers will have difficulty in exploiting the benefits of the abolition of MFN tariffs in these categories in the EU markets.

Overall, the analysis suggests that there may be some products in LDCs that will run the risk of undergoing losses in the form of market share or suffer deterioration in terms of trade in the EU markets as a result of revised the GSP or signing of FTAs as also TTIP. This will be the case particularly for those products where EU MFN tariffs are high. However, as third countries are not in the room when these FTAs are negotiated, policy options are limited for them. This is the case for LDCs as well. LDCs such as Bangladesh could ask for compensation for preference erosion induced by the new trade policy of EU which is also compatible under Article XXIV of the General Agreement on Tariffs and Trade (GATT).

However, unless export baskets are more diversified, Bangladesh will not be able to fully enjoy the preferential benefit of the EBA. Current preference on export items will suffer gradual erosion and competing countries including Pakistan, India and Vietnam are likely to take away some of Bangladesh's market share in the EU. Bangladesh will need to diversify her exports to sustain and capture more market share in the EU market. At present, Bangladesh's ambition is to attain middle income country status by 2021 . When a country no longer belongs to the LDC category, it will be removed from the EBA list after a three year transitional period. Consequently, Bangladesh will need to develop her capacity to compete with the other developing countries on the same footing. Thus, Bangladesh will have to push her utmost emphasis on strengthening infrastructure, encouraging innovation, promoting productivity, reducing corruption and attaining good governance in the relevant sectors to realize her potential in a dynamic global market by ensuring her presence from a position of strength and high competitiveness. 


\section{References}

Armington, Paul S. (1969) "A Theory of Demand for Products Distinguished by Place of Production” IMF Staff Papers, V.16, no.1, pp. 159-176

Bangladesh Export Promotion Bureau (2012) "Trend of Bangladesh Exports" www.epb.gov.bd

Brown, Drusilla K., Alan V. Deardorff and Robert M. Stern (2003) "Multilateral, Regional and Bilateral Trade Options for the United States and Japan" World Economy 26:6, 803- 828 .

International Monetary Fund (2012) Directions of Trade Statistics (DOTS) CD-ROM Database, IMF, Washington DC

Gasiorek M. et al. (2010) Mid-term Evaluation of the EU's Generalised System of Preferences, Centre for Analysis for Regional Integration at Sussex, University of Sussex.

Hertel, T.W. (ed.) (1997), Global Trade Analysis: Modeling and Applications, Cambridge and New York: Cambridge University Press.

Kawai, M. and Ganeshan W. (2007) "ASEAN+3 or ASEAN+6: Which Way Forward?" ADBI Discussion Paper 77, Asian Development Bank Institute, Tokyo:

Kawasaki (2003) "The Impact of Free Trade Agreements in Asia", RIETI Discussion Paper Series 03- E- 018

Memo 12-820-EN October 31, 2013 European Parliament, EU, Brussels, www.ec.europa.eu.

Mohanty, S.K. and Sanjib P (2007) "Welfare Gains from Regional Economic Integration in Asia: ASEAN+3 or EAS," RIS Discussion Paper No. 126, New Delhi: RIS.

Raihan S. (2009) "EU-India Bilateral FTA: Potential Implications for the Excluded LowIncome Economies in Asia and Africa", UNESCAP Conference proceedings 
http://www.unescap.org/tid/artnet/mtg/Selim\%20Raihan.pdf.

Regulation (EU) No. 978/2012 (2013) Official Journal of the European Union, European Parliament, EU, Brussels http://europa.eu/lisbon_treaty/full_text/

Regional Trade Agreements (2013) World Trade Organization (WTO, Geneva, Switzerland http://www.wto.org/english/tratop_e/region_e/region_e.htm (accessed on June 10, 2013)

Siriwardana M. and Yang J. (2008) "GTAP Model Analysis of the Economic Effects of an Australia-China FTA: Welfare and Sectoral Aspects" Global Economic Review, Volume 37, No 3, Pages: 341-362, Taylor and Francis

Thierfelder K. et al. (2007) Asian Growth Poles: Implications of Trade Liberalization and Economic Integration by China and India for Other Developing Countries," Presented at the 10th Annual Conference on Global Economic Analysis, June 7-9, Purdue University

TradeSift. 2012. Systematic Integrated Framework for Data Analysis, version 2.0.9, http://www.tradesift.com

Trade and Investment Division, United Nations Economic Cooperation for Asia Pacific (2012) APTIAD-UNESCAP, www.unescap.org/tid/aptiad

Wacziarg, R. (1997) “Trade, Competition and market Size", Cambridge, MA: Harvard University.

Winters, L Alan, et.al (2009) Innocent Bystanders: Implications of an EU-India free trade agreement for excluded countries. Commonwealth Secretariat, United Kingdom

Annex 1. Regional and Commodity Aggregation of GTAP Database

\begin{tabular}{|c|c|c|c|c|c|}
\hline SL & $\begin{array}{c}\text { Aggregated } \\
\text { Region }\end{array}$ & GTAP Region & SL & Aggregated Commodities & GTAP Commodities \\
\hline 1 & Bangladesh & Bangladesh & 1 & Primary (15) & $\begin{array}{c}\text { pdr wht gro v_f osd c_b } \\
\text { pfb ocr ctl oap rmk wol frs } \\
\text { fsh cmt }\end{array}$ \\
\hline 2 & India & India & 2 & Natural Resources (4) & coa oil gas omn \\
\hline
\end{tabular}




\begin{tabular}{|c|c|c|c|c|c|}
\hline SL & $\begin{array}{l}\text { Aggregated } \\
\text { Region }\end{array}$ & GTAP Region & SL & Aggregated Commodities & GTAP Commodities \\
\hline 3 & Pakistan & Pakistan & 3 & Light Engineering (12) & $\begin{array}{c}\text { omt vol mil pcr sgr ofd } b_{-} t \\
\text { lea lum ppp nmm omf }\end{array}$ \\
\hline 4 & Sri Lanka & Sri Lanka & 4 & Textile and Apparel (2) & tex wap \\
\hline 5 & Viet Nam & Viet Nam & 5 & Chemical and Metal (5) & p_c crp i_s nfm fmp \\
\hline 6 & China & China & 6 & $\begin{array}{l}\text { Machinery and Equipment } \\
\text { (1) }\end{array}$ & ome \\
\hline 7 & Japan & Japan & 7 & $\begin{array}{c}\text { Transport and } \\
\text { communication (2) }\end{array}$ & mvh otn \\
\hline 8 & Korea & Korea & 8 & Electronic equipment (1) & ele \\
\hline 9 & USA & $\begin{array}{c}\text { United States of } \\
\text { America }\end{array}$ & 9 & Service (15) & $\begin{array}{c}\text { ely gdt wtr cns trd otp wtp } \\
\text { atp cmn ofi isr obs ros osg } \\
\text { dwe }\end{array}$ \\
\hline 10 & Canada & Canada & & & \\
\hline 11 & EU 27 & $\begin{array}{c}\text { EU } 27 \\
\text { Countries }\end{array}$ & & & \\
\hline 12 & RLDCs & $\begin{array}{l}\text { Rest of } 48 \\
\text { LDCs }\end{array}$ & & & \\
\hline 13 & RoW & $\begin{array}{c}\text { Rest of } 44 \\
\text { countries in the } \\
\text { World of GTAP } \\
\text { Database }\end{array}$ & & & \\
\hline
\end{tabular}

Source: GTAP version 8 